\title{
PENGARUH WAKTU MASERASI TERHADAP AKTIVITAS ANTIOKSIDAN EKSTRAK KULIT BUAH JERUK LEMON (Citrus limon Linn)
}

\author{
Dyta Aprida Asendy ${ }^{1}$, I Wayan Rai Widarta ${ }^{2}$, Komang Ayu Nocianitri ${ }^{2}$ \\ ${ }^{1}$ Mahasiswa Jurusan Imu dan Teknologi Pangan, Fakultas Teknologi Pertanian, Unud \\ ${ }^{2}$ Dosen Jurusan Imu dan Teknologi Pangan, Fakultas Teknologi Pertanian, Unud \\ PS Ilmu dan Teknologi Pangan, Fakultas Teknologi Pertanian, Universitas Udayana, \\ Kampus Bukit Jimbaran, Badung-Bali
}

\begin{abstract}
This research aimed to find effect of maceration time on antioxidant activity of lemon peel extract and to knew the best maceration time with highest antioxidant activity of lemon peel extract. This study used a Randomized Completly Design with treatment of maceration time of 6 levels: 18 hours, 24 hours, 30 hours, 36 hours, 42 hours and 48 hours. The experiment was repeated in three replication, so that 18 experimental units were obtained. The data were analyzed by ANOVA and then continued with DMRT. The results showed that the treatment of maceration time had significant effect on extraction yield, vitamin $C$, total phenol, total flavonoids and antioxidant activity of lemon peel extract. The best treatment was 36 hours with extraction yield was $26.96 \%$, vitamin C was $5.22 \mathrm{mg} \mathrm{AA/g}$, total flavonoids was $69.64 \mathrm{mg} Q \mathrm{E} / \mathrm{g}$, total phenol was $16.73 \mathrm{mg} \mathrm{GAE} / \mathrm{g}$ and antioxidant activity was $94.08 \%$.
\end{abstract}

Keywords: antioxidant activity, maceration time, lemon peel.

\section{PENDAHULUAN}

Jeruk lemon (Citrus limon Linn) adalah salah satu bahan pangan yang telah banyak dibudidayakan dan digunakan secara komersial sebagai bahan baku bagi berbagai industri, khususnya industri pengolahan minuman sari buah lemon. Industri minuman sari buah jeruk lemon hanya dapat memanfaatkan $45 \%$ bagian buah dan sisanya masih merupakan limbah berupa kulit dan pulp. Komposisi buah jeruk lemon adalah sari buah sebanyak (45\%), kulit bagian luar, kulit bagian dalam dan sisa perasan bulir buah sebanyak (55\%) (Lilaharta, 2005). Hasil pengamatan pada industri pengolahan sari buah lemon (PT. Kumia Abadi Sejahtera) mampu mengolah buah lemon sebanyak 1,5 ton/hari sehingga volume limbah yang dihasilkan akan mencapai 1,05 ton/hari. Limbah ini merupakan masalah besar bagi industri karena sifat asam dari limbah jeruk lemon ini akan menurunkan $\mathrm{pH}$ tanah sehingga menyebabkan berkurangnya kelarutan oksigen pada tanah yang selanjutnya menurunkan tingkat kesuburan tanah. Selain itu adanya kandungan protein dan karbohidrat pada limbah jeruk lemon ini dapat menimbulkan bau busuk jika dibuang begitu saja (Meilina $e t$ al., 2014).

Kulit jeruk lemon memiliki kandungan senyawa fenolik dan minyak atsiri (oleoresin). Senyawa fenolik yang terkandung dalam kulit jeruk lemon terdiri atas flavonoid dan asam fenolik (Akhila et al., 2009). Kulit buah jeruk lemon mengandung senyawa fenolik sebesar $9,7 \mathrm{mg} \mathrm{GAE} / \mathrm{g}$, senyawa flavonoid sebanyak 18,1 mg QE/g (Agarwal et al., 2012), dan

*Korespondensi Penulis:

Email: dytacendy@gmail.com ${ }^{1}$ 
vitamin C sebanyak 59,8 mg AAE/100g (Goristein et al., 2001). Dahmoune et al., (2013) melaporkan bahwa total fenolik pada kulit jeruk lemon dengan menggunakan metode ultrasonik dan microwave assisted adalah sebesar 15,78mg GAE/g dan 15,22 mg GAE/g. Senyawa fenolik ini memiliki banyak manfaat diantaranya sebagai anti mikroba, obat infeksi pada luka, anti virus, anti kanker, anti tumor, anti alergi dan anti hipertensi (Sriningsih, 2008).

Pengambilan senyawa fenolik dari suatu tanaman dapat dilakukan dengan ekstraksi. Ekstraksi kulit buah jeruk lemon dapat dilakukan beberapa metode diantaranya metode maserasi, metode perkolasi dan metode soxhlet. Metode maserasi memiliki beberapa kelebihan diantaranya adalah biayanya yang murah, mudah untuk dilakukan, mudah diaplikasikan dan tanpa pemanasan sehingga tidak merusak senyawa fenolik yang terkandung dalam bahan (Cuppet et al., 1954). Pengujian secara kualitatif pada ekstrak kulit buah jeruk lemon dengan metode maserasi selama 120 jam menunjukkan hasil positif adanya senyawa fenolik (Akhila et al., 2009).

Selama proses ekstraksi, senyawa fitokimia akan terlarut oleh pelarut yang sesuai dengan sifat kepolarannya. Senyawa fenolik bersifat polar sehingga dibutuhkan pelarut yang bersifat polar (Gillespie dan Paul, 2001). Etanol bersifat polar, tidak berwarna, tidak beracun, volatil (mudah menguap), dapat bercampur dengan air serta food grade (Kartika et al., 1997). Etanol 95\% telah digunakan sebagai pelarut pada proses maserasi kulit buah jeruk bali oleh Abhishek et al., (2011) untuk mendapatkan kandungan senyawa fenolik dan aktivitas antioksidan.

Selain jenis pelarut, waktu ekstraksi juga dapat mempengaruhi hasil ekstraksi. Waktu maserasi yang tepat dapat menghasilkan rendemen dan total senyawa fenolik yang tinggi. Waktu maserasi yang terlalu singkat akan mengakibatkan senyawa fenolik yang larut dalam pelarut berjumlah sedikit, dan apabila waktu maserasi terlalu lama maka akan mengakibatkan rusaknya senyawa fenolik yang diekstrak (Utami, 2009). Bahan simplisia memiliki waktu optimum yang berbeda beda. Akhila et al., (2009) melaporkan bahwa waktu maserasi dalam penentuan total fenolik, total flavonoid dan aktivitas antioksidan pada kulit jeruk lemon adalah 120 jam, sedangkan Abhishek et al., (2011) melaporkan bahwa waktu maserasi pada penentuan total fenolik dan aktivitas antioksidan pada kulit jeruk bali adalah 72 jam. Waktu maserasi yang digunakan pada penelitian sebelumnya membutuhkan waktu yang sangat lama, oleh karena itu tujuan penelitian ini adalah untuk mendapatkan waktu maserasi yang tepat dalam menghasilkan ekstrak kulit buah jeruk lemon dengan aktivitas antioksidan tertinggi.

\section{METODE PENELITIAN}

\section{Tempat dan waktu penelitian}

Penelitian ini dilaksanakan di Laboratorium Analisis Pangan dan Laboratorium Pengolahan Pangan, Program Studi Ilmu dan Teknologi Pangan, Fakultas Teknologi Pertanian, Universitas Udayana, Kampus Sudirman. Penelitian ini dilakukan pada bulan Januari 2018 sampai dengan bulan Maret 2018.

\section{Bahan dan Alat}

Bahan yang digunakan dalam penelitian ini adalah kulit buah jeruk lemon lokal yang berasal dari daerah Baturiti, Tabanan, etanol, aquades, $\mathrm{NaNO} 2, \mathrm{AlCl} 3, \mathrm{NaOH}$, asam askorbat, $\mathrm{H} 2 \mathrm{SO} 4$, ammonium molibdat, asam galat, reagen Folin-Ciocalteu, buffer fosfat, asam trikloroasetat, $\mathrm{K} 3 \mathrm{Fe}(\mathrm{CN}) 6, \mathrm{FeCL} 3$, dan sodium karbonat.

Alat yang digunakan dalam penelitian ini adalah tabung reaksi (pyrex), blender (phillips), Erlenmeyer (pyrex), pisau, centrifuge, timbangan analitik (Shimadzu), rotary vakum evaporator (Ika Labortechnik), cawan porselen, ayakan 60 mesh, wadah maserasi, vortex, botol gelap, pipet mikro 
(Socorex), pipet ukur (pyrex), gelas ukur (pyrex), gelas beker (pyrex), labu ukur (pyrex), water bath (memmert), sendok, bulb dan spektrofotometer UV-Vis (Genesys 10s Uv-Vis).

\section{Pelaksanaan Penelitian}

\section{Pembuatan Bubuk Kulit Jeruk Lemon}

Kulit buah jeruk lemon dipotong dengan ukuran $+0,5 \mathrm{~cm} 2$, kemudian dikeringkan menggunakan oven dengan suhu 55oC selama 15 jam. Kulit jeruk lemon yang telah dikeringkan, dihancurkan menggunakan blender, kemudian diayak dengan ayakan 60 mesh. (Fitriani, 2013).

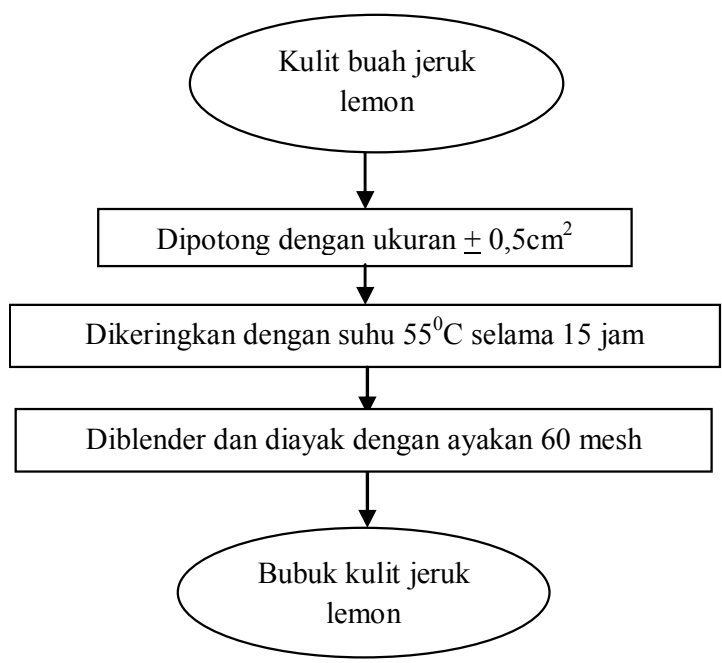

Gambar 1. Diagram alir proses pembuatan bubuk kulit jeruk lemon (Fitriani, 2013), yang dimodifikasi)

\section{Proses ekstraksi}

Bubuk kulit jeruk lemon ditimbang sebanyak 15 g, kemudian dimasukkan dalam wadah tertutup dan terlindung cahaya, kemudian ditambahkan pelarut etanol 96\% sebanyak $150 \mathrm{ml}$ dengan rasio $1: 10(\mathrm{~b} / \mathrm{v})$. Maserasi dilakukan selama : 18, 24, 30, 36, 42, dan 48 jam pada suhu kamar (sesuai perlakuan). Larutan kemudian disaring menggunakan kertas Whatman no 1. Filtrat yang didapat kemudian dievaporasi menggunakan rotary vakum evaporator
(Widarta et al.,(2013) yang dimodifikasi).

\section{Rancangan Percobaan dan Analisis Data}

Penelitian ini menggunakan Rancangan Acak Lengkap (RAL) dengan faktor waktu maserasi yang terdiri dari 6 taraf $\mathrm{W} 1=18$ jam, $\mathrm{W} 2=24$ jam, W3 $=30$ jam, W4 $=36$ jam, W5 $=42$ jam dan $\mathrm{W} 6=48$ jam. Percobaan diulang sebanyak tiga kali ulangan, sehingga diperoleh 18 unit percobaan. Data yang diperoleh dianalisis dengan sidik ragam dan apabila terdapat pengaruh perlakuan terhadap parameter yang diamati, maka akan dilanjutkan dengan uji Duncan's Multiple Range Test (DMRT) dengan tingkat signifikansi $\mathrm{P}<0,05$ (Steel dan Torrie, 1993).

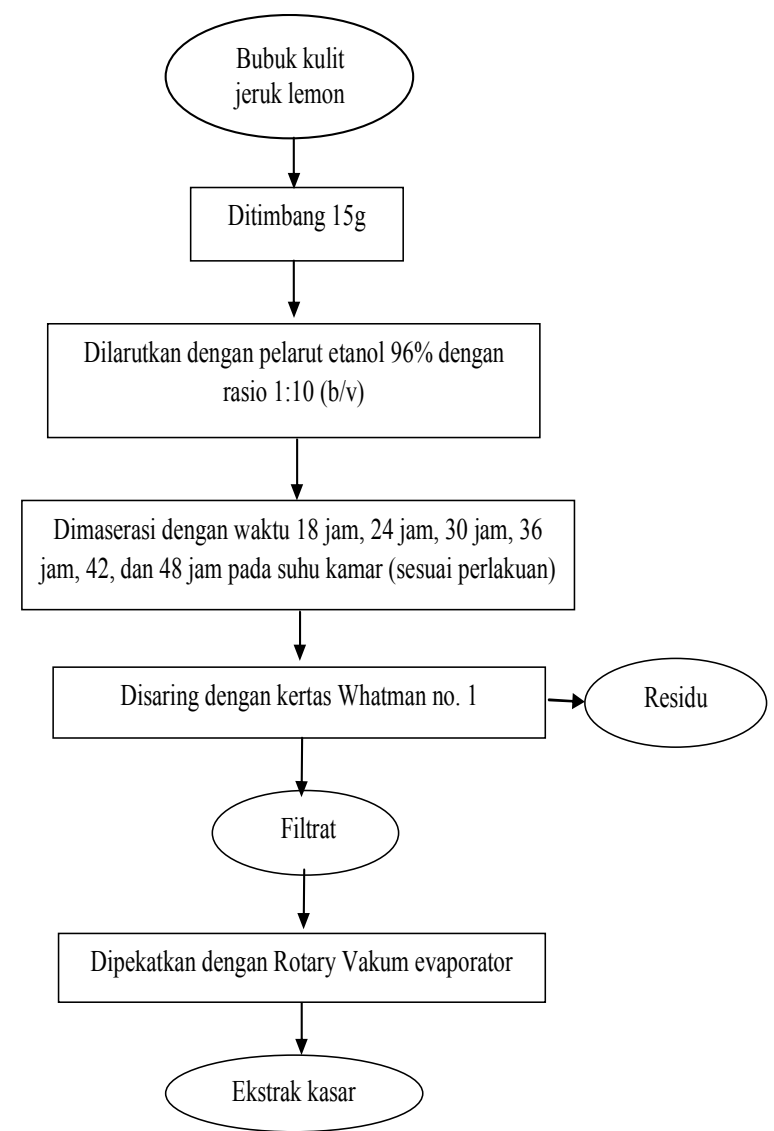

Gambar 2. Diagram alir proses Ekstraksi Kulit buah jeruk lemon (Widarta et al., 2013), yang dimodifikasi)

\section{Parameter yang Diamati}

Parameter yang diamati yaitu rendemen 
(Jayanudin et al., 2014), kadar vitamin C dengan metode spektrofotometri (vuong et al., 2014), total fenol dengan metode FolinCiocalteu (Garcia et al., 2007), total flavonoid (Xu dan Chang, 2012), dan aktivitas antioksidan dengan metode daya reduksi (Rajan et al., 2011).

\section{HASIL DAN PEMBAHASAN}

Hasil analisis ragam menunjukkan bahwa waktu maserasi berpengaruh nyata $(\mathrm{P}<0,05)$ terhadap rendemen, vitamin $\mathrm{C}$, total fenol, total flavonoid dan aktivitas antioksidan pada ekstrak kulit buah jeruk lemon. Nilai rata-rata rendemen, vitamin $\mathrm{C}$, total fenol, total flavonoid dan aktivitas antioksidan ekstrak kulit buah jeruk lemon pada perlakuan waktu maserasi dapat dilihat pada Tabel 1 .

\section{Rendemen}

Hasil analisis ragam menunjukkan bahwa waktu maserasi berpengaruh nyata $(\mathrm{P}<0,05)$ terhadap total rendemen ekstrak kulit buah jeruk lemon. Hasil penelitian menunjukkan bahwa rendemen tertinggi diperoleh dari perlakuan dengan waktu maserasi selama 30 jam (W3) yaitu 27,23\%. Rendemen terendah diperoleh dari perlakuan dengan waktu maserasi paling singkat yaitu selama 18 jam (W1) yaitu sebesar 24,93\%. Rendemen ekstrak kulit buah jeruk lemon mengalami peningkatan dalam rentang waktu 18 sampai 30 jam. Semakin lama waktu maserasi maka akan semakin tinggi rendemen yang dihasilkan sampai mencapai titik optimum ekstraksi, setelah titik optimum tercapai hasil rendemen mengalami penurunan yang tidak signifikan. Kemit et al., (2015) melaporkan bahwa semakin lama waktu maserasi, maka kesempatan kontak antara bahan dan pelarut semakin besar sehingga hasil ekstraksinya akan terus meningkat sampai pada titik jenuh dari pelarut tersebut. Waktu maserasi optimum pada ekstraksi kulit buah jeruk lemon adalah selama 30 jam, setelah waktu maserasi melebihi 30 jam rendemen ekstrak kulit buah jeruk lemon berbeda tidak nyata. Semakin lama waktu maserasi, maka senyawa terlarut akan terus terlarut kedalam pelarut sampai pada titik jenuh dari pelarut tersebut, setelah titik jenuh tercapai maka senyawa terlarut tidak lagi larut, hal ini akan menyebabkan hasil rendemen tidak lagi bertambah namun cenderung tetap atau mengalami penurunan yang tidak signifikan. Hal ini sesuai dengan yang dilaporkan Utami (2009), yaitu waktu ekstraksi yang terlalu lama dan melewati batas optimum proses ekstraksi akan menyebabkan rusaknya senyawa fitokimia yang terekstrak, sehingga mempengaruhi hasil ekstrak yang didapatkan. Nilai rendemen menunjukkan bobot senyawa metabolit sekunder yang dapat terekstrak dari suatu sampel. Semakin tinggi rendemen menunjukan semakin tinggi ekstrak yang diperoleh (Tiwari et al., 2011).

\section{Kadar Vitamin C}

Hasil analisis ragam menunjukkan bahwa waktu maserasi berpengaruh nyata $(\mathrm{P}<0,05)$

Tabel 1. Nilai rata- rata rendemen, vitamin $\mathrm{C}$, total fenol, total flavonoid dan aktivitas antioksidan ekstrak kulit buah jeruk lemon pada perlakuan waktu maserasi.

\begin{tabular}{|c|c|c|c|c|c|}
\hline $\begin{array}{c}\text { Waktu } \\
\text { Maserasi } \\
\text { (jam) }\end{array}$ & Rendemen (\%) & $\begin{array}{c}\text { Vitamin C (mg/g } \\
\text { ekstrak) }\end{array}$ & $\begin{array}{c}\text { Total Flavonoid } \\
\text { (mg/g ekstrak) }\end{array}$ & $\begin{array}{c}\text { Total Fenolik } \\
\text { (mg/g ekstrak) }\end{array}$ & $\begin{array}{c}\text { Aktivitas } \\
\text { Antioksidan (\%) }\end{array}$ \\
\hline W1 (18) & $24,94 \pm 0,50 \quad b$ & $4,88 \pm 0,27$ & $65,29+1,33 \mathrm{~cd}$ & $12,21+0,25 \mathrm{~d}$ & $77,26 \pm 1,42 \quad \mathrm{c}$ \\
\hline W2 (24) & $26,38 \pm 2,09 \mathrm{ab}$ & $5,48 \pm 0,42$ & $106,08+3,69$ a & $13,55 \pm 0,50 \mathrm{c}$ & $81,93 \pm 1,42 \quad b$ \\
\hline W3 (30) & $27,23 \pm 0,91 \quad$ a & $5,40 \pm 0,20$ & $73,94 \pm 2,42 \quad b$ & $14,73 \pm 0,41 \mathrm{~b}$ & $86,29 \pm 1,42 \quad b$ \\
\hline W4 (36) & $26,96+1,01 \mathrm{ab}$ & $5,22+0,09$ & $69,64+4,57$ bc & $16,73 \pm 0,45 \mathrm{a}$ & $94,08 \pm 2,85$ a \\
\hline W5 (42) & $26,84 \pm 1,11 \mathrm{ab}$ & $5,01 \pm 0,10$ & $64,41 \pm 3,80$ & $15,18 \pm 0,17 \mathrm{~b}$ & $75,39 \pm 4,21 \quad \mathrm{c}$ \\
\hline W6 (48) & $26,78 \pm 0,49 \mathrm{ab}$ & $4,89 \pm 0,12$ & $60,11 \pm 3,67$ & $14,97 \pm 0,22 \mathrm{~b}$ & $63,55 \pm 2,80 \mathrm{~d}$ \\
\hline
\end{tabular}

Keterangan : Notasi yang sama pada kolom yang sama menunjukan perlakuan tidak berpengaruh nyata $(\mathrm{P}>0,05)$. 
terhadap kadar vitamin C ekstrak kulit buah jeruk lemon. Hasil penelitian menunjukkan bahwa kadar vitamin $\mathrm{C}$ tertinggi diperoleh dari perlakuan dengan waktu maserasi selama 24 jam (W2) yaitu 5,48 mg AA/g ekstrak. Kadar vitamin $\mathrm{C}$ terendah diperoleh dari perlakuan dengan waktu maserasi selama 18 jam (W1) yaitu 4,88 $\mathrm{mg}$ AA/g ekstrak. Hal ini menunjukan bahwa waktu maserasi optimum untuk memperoleh vitamin $\mathrm{C}$ yang optimal dalam ekstrak kulit buah jeruk lemon adalah selama 24 jam, setelah waktu maserasi diatas 24 jam menyebabkan kadar vitamin $\mathrm{C}$ dalam ekstrak kulit buah jeruk lemon semakin rendah. Waktu maserasi yang semakin lama menyebabkan peningkatan jumlah vitamin $\mathrm{C}$ yang terlarut dalam pelarut, namun setelah mencapai waktu optimumnya yaitu selama 24 jam, jumlah vitamin $\mathrm{C}$ semakin berkurang. Menurut Janati et al., (2012) kulit jeruk lemon mengandung logam $\mathrm{Cu}$ sebesar $0,22 \mathrm{mg}$ dan logam besi sebesar $0,54 \mathrm{mg}$. Kandungan besi dan $\mathrm{Cu}$ dalam kulit jeruk lemon dapat mengakibatkan terjadinya oksidasi pada vitamin C. Menurut Jourkesh et al., (2011) vitamin $\mathrm{C}$ mudah teroksidasi oleh beberapa logam utama seperti $\mathrm{Fe}, \mathrm{Ag}$ dan $\mathrm{Cu}$. Hal ini sesuai dengan yang dilaporkan oleh Safaryani (2007), asam askorbat bersifat sangat sensitif terhadap pengaruh luar penyebab kerusakan seperti suhu, oksigen dan katalisator logam.

\section{Total Flavonoid}

Hasil analisis ragam menunjukkan bahwa waktu maserasi berpengaruh nyata $(\mathrm{P}<0,05)$ terhadap total flavonoid ekstrak kulit buah jeruk lemon. Hasil penelitian menunjukkan bahwa kadar total flavonoid tertinggi diperoleh dari perlakuan dengan waktu maserasi selama 24 jam (W2) yaitu 106,08 mg QE/g ekstrak. Kadar total flavonoid terendah diperoleh dari perlakuan dengan waktu maserasi selama 48 jam (W6) yaitu 60,11 mg QE/g ekstrak. Senyawa flavonoid mengalami peningkatan pada waktu maserasi 18 sampai 24 jam. Hal ini menunjukkan bahwa waktu maserasi optimum untuk mendapatkan total flavonoid tertinggi adalah selama 24 jam, setelah waktu maserasi 24 jam menyebabkan kadar total flavonoid dalam ekstrak kulit buah jeruk lemon semakin rendah. Hal ini disebabkan karena dengan semakin lama maserasi maka semakin lama pula kontak antara bahan dengan pelarut sehingga kandungan senyawa flavonoid semakin meningkat, namun bila maserasi terlalu lama juga dapat menyebabkan penurunan kandungan senyawa flavonoid pada ekstrak kulit jeruk lemon. Hal ini dikarenakan waktu maserasi yang terlalu lama menyebabkan senyawa flavonoid yang terekstrak menjadi rusak. Hal ini sesuai dengan pernyataan Utami, (2009) yang melaporkan bahwa waktu ekstraksi dapat mempengaruhi hasil ekstraksi. Waktu ekstraksi yang tepat dapat menghasilkan rendemen dan total senyawa fitokimia yang tinggi. Namun waktu ekstraksi yang melewati batas optimum proses ekstraksi akan menyebabkan rusaknya senyawa fitokimia yang terekstrak.

\section{Total Fenolik}

Hasil analisis ragam menunjukkan bahwa waktu maserasi berpengaruh nyata $(\mathrm{P}<0,05)$ terhadap total fenol ekstrak kulit buah jeruk lemon. Hasil analisis ragam yang menunjukkan total fenol tertinggi dan mencapai titik jenuhnya terdapat pada perlakuan waktu selama 36 jam (W4) yaitu $16,73 \mathrm{mg} \mathrm{GAE} / \mathrm{g}$ dan total fenol terendah terdapat pada perlakuan waktu maserasi yang paling singkat yaitu 18 jam (W1) sebesar $12,20 \mathrm{mg} \mathrm{GAE} / \mathrm{g}$ ekstrak. Waktu ekstraksi sangat berpengaruh terhadap hasil ekstraksi. Semakin lama waktu maserasi akan menyebabkan semakin banyaknya penetrasi pelarut ke dalam bahan, hal ini menyebabkan senyawa fitokimia semakin larut kedalam pelarut yang digunakan. Semakin lama waktu ekstraksi, jumlah fenol yang terekstrak semakin besar, ini akan terus bertambah sampai pada batas waktu optimum proses 
ekstraksi. Seperti yang dilaporkan oleh (Kemit et al., 2015) semakin lama waktu maserasi, maka kesempatan kontak antara bahan dan pelarut semakin besar sehingga hasilnya akan terus meningkat sampai pada titik jenuh dari pelarut tersebut. Setelah mencapai waktu optimumnya senyawa fenolik mengalami kerusakan dan tidak lagi terlarut kedalam pelarut yang digunakan. Hal ini sesuai dengan yang dilaporkan Utami (2009) yaitu waktu ekstraksi yang tepat dapat menghasilkan rendemen dan total senyawa fitokimia yang tinggi. Namun waktu ekstraksi yang melewati batas optimum proses ekstraksi akan menyebabkan rusaknya senyawa fitokimia yang terekstrak.

\section{Aktivitas Antioksidan}

Aktivitas antioksidan ditentukan menggunakan metode daya reduksi. Daya reduksi merupakan indikator potensi suatu senyawa sebagai antioksidan. Hasil analisis ragam menunjukkan bahwa waktu maserasi berpengaruh nyata $(\mathrm{P}<0,05)$ terhadap aktivitas antioksidan ekstrak kulit buah jeruk lemon. Berdasarkan hasil penelitian, aktivitas antioksidan ekstrak kulit buah jeruk lemon tertinggi diperoleh pada perlakuan waktu maserasi selama 36 jam (W4) yaitu sebesar 94,08 \% dan aktivitas antioksidan terendah pada perlakuan waktu maserasi selama 48 jam (W6) sebesar $63,55 \%$. Serupa dengan aktivitas antioksidan pada ekstrak kulit buah jeruk bali sebesar 60\% (Abhiseik et al., 2011). Aktivitas antioksidan semakin tinggi hingga optimal pada waktu maserasi selama 36 jam, setelah waktu maserasi 36 jam aktivitas antioksidan mengalami penurunan. Aktivitas antioksidan meningkat seiring dengan meningkatnya kandungan senyawa fitokimia yang terdapat dalam ekstrak, namun setelah waktu optimum tercapai aktivitas antioksidan semakin berkurang selaras dengan penurunan kandungan senyawa fitokimianya. Hal ini menunjukkan bahwa terdapat hubungan positif antara total fenol dan aktivitas antioksidan dalam mereduksi ion besi. Senyawa fenolik memiliki gugus hidroksil sehingga mampu mendonorkan elektronnya dengan mereduksi $\mathrm{Fe}^{3+}$ menjadi $\mathrm{Fe}^{2+}$ (Jourkesh et al., 2011). Berdasarkan hasil analisis persentase daya reduksi, diperoleh perlakuan waktu maserasi 36 jam memiliki persentase daya reduksi tertinggi. Oleh karena itu dipilih untuk diuji lanjut yaitu penentuan $\mathrm{IC}_{50}$. Hasil analisis regresi linier dalam penentuan $\mathrm{IC}_{50}$ diperoleh persamaan $\mathrm{y}=0,1369 \mathrm{x}-58,641$ dengan nilai $\mathrm{IC}_{50}$ sebesar $793 \mathrm{mg} / \mathrm{L}$.

Vitamin $\mathrm{C}$ juga berpengaruh terhadap aktivitas antioksidan ekstrak kulit buah jeruk lemon. Menurut Kumalaningsih (2006), vitamin $\mathrm{C}$ tergolong dalam antioksidan alami, sedangkan berdasarkan pada fungsinya vitamin $\mathrm{C}$ tergolong dalam antioksidan sekunder dan oxygen scavanger. Vitamin C termasuk golongan vitamin antioksidan yang mampu menangkal berbagai radikal bebas ekstraseluler. vitamin $\mathrm{C}$ merupakan donor elektron dan agen pereduksi. Disebut antioksidan, karena dengan mendonorkan elektronnya, vitamin ini mencegah senyawasenyawa lain agar tidak teroksidasi. Kandungan fenolik, flavonoid dan vitamin C sangat mempengaruhi aktivitas antioksidan pada ekstrak kulit buah jeruk lemon.

\section{SIMPULAN DAN SARAN}

\section{Simpulan}

Berdasarkan dari hasil penelitian yang sudah dilakukan, dapat disimpulkan sebagai berikut :

1. Perlakuan waktu maserasi ekstrak kulit buah jeruk lemon berpengaruh nyata terhadap rendemen, kadar vitamin $\mathrm{C}$, total flavonoid, total fenol dan aktivitas antioksidan.

2. Perlakuan terbaik adalah perlakuan waktu maserasi selama 36 jam (W4) dengan rendemen sebesar $26,96 \%$, kadar vitamin $\mathrm{C}$ sebesar 5,22 $\mathrm{mg} \mathrm{AAE} / \mathrm{g}$, total flavonoid sebesar 69,64 mg QE/g, total fenol sebesar 
16,73 $\mathrm{mg} \mathrm{GAE} / \mathrm{g}$ dan aktivitas antioksidan sebesar 94,08\% dengan IC50 $793 \mathrm{mg} / \mathrm{L}$.

\section{Saran}

Berdasarkan hasil penelitian ini disarankan agar dilakukan kajian mengenai mekanisme kerja senyawa bioaktif yang terdapat pada ekstrak kulit buah jeruk lemon dengan berbagai metode pengujian aktivitas antioksidan lainnya.

\section{DAFTAR PUSTAKA}

Abhishek, M., S.K. Verma dan S.K. Singh. 2011. Evaluation of in vitro microbacterial and antioxidant activities of peel and pulp some citrus fruit. Journal of Biotechnology and Biotherapeutic. Vol 1 (2) : 1-18.

Agarwal, M., R. Gupta dan S. Upadhyaya. 2012. Extraction of polyphenol, flavonoid from Emblica officinalis, Citrus limon, Cucumis sativus and evaluation of their antioxidant activity. Oriental Journal of Chemistry. 28(2): 993-998.

Akhila, S., A.R. Bindu dan N.A. Alleykutti. 2009. Comparative evaluation of extract of citrus limon burn peel for antioxidant activity. J Young Pharm. Vol 1 No. 2 : 136144.

Cuppett, S., M. Schrepf dan C. Hall. 1954. Natural Antioxidant - Are They Reality. Dalam Foreidoon Shahidi: Natural Antioxidants, Chemistry, Health Effect and Applications. AOCS Press, Champaign. Illinois: 12-24.

Dahmoune, F., K. Moussi dan K. Madani. 2013. Valorization of citrus limon residues for the recovery antioxidant : evaluation and optimation of microwave and ultrasound application to solvent reaction. Journal Industrial Crop and Product. 50 : 77-87.
Fitriani, V. 2013. Ekstraksi dan Karakterisasi Pektin dari Kulit Jeruk Lemon (Citrus medica Var Lemon). Skripsi. Tidak dipublikasikan. Institut pertanian Bogor, Bogor.

Garcia, C.A., P. Hevia dan V.C. Gravino. 2007. Correlation of tocopherol, tokotrienol and total polyphenol content in rice bran with different antioxidant capacity assays. J. Food Chem. 102:1228-1232.

Gillespie, R. J. P. 2001. Chemical Bonding and Molecular Geometry. Oxford University Press, London.

Goristein, S., O.M. Belloso dan C. Milan. 2001. Comparison of biochemical characteristic of different citrus fruit. Food Chemistry. $74:$ 309-315.

Jayanudin, A. Z. Lestari dan F. Nurbayanti. 2014. Pengaruh suhu dan rasio pelarut ekstraksi terhadap rendemen dan viskositas natrium alginat dari rumput laut cokelat (Sargassum $s p$ ). Jurnal Integrasi Proses. 5(1):51-56.

Jourkesh, M., I. Sadri dan M. Dehyanpoori. 2011. The effects of two different doses of antioxidant vitamin $\mathrm{C}$ supplementation on bioenergetics index in male college student. Journal of American Science. 6 : 852-858.

Kartika, B., A. D. Guritno dan Ismoyowati. 1997. Evaluasi Produk Industri Hasil pertanian. Universitas gajah Mada, Yogyakarta.

Kemit, N., I. W. R. Widarta dan K.A. Nocianitri. 2015. Pengaruh jenis pelarut dan waktu maserasi terhadap kandungan senyawa flavonoid dan aktivitas antioksidan ekstrak daun alpukat (Persea Americana Mill). E Jurnal Itepa Universitas 
Udayana. 1: 130-141.

Kumalaningsih, S. 2006. Antioksidan Alami. Cetakan I. Trubus Agrisarana, Surabaya.

Lilaharta, I. N. 2005. Studi Pemanfaatan Kulit Jeruk Lemon (Citrus medica var lemon) menjadi Selai. Skripsi. Tidak Dipublikasikan. Institut Pertanian Bogor, Bogor.

Meiliana, H. dan I. Sailah. 2014. Produksi pektin dari kulit jeruk lemon (Citrus medica). Jurnal Prosiding Simposium Nasional Polimer. 5(1): 117-126.

Rajan, S., S. Mahalaksmi dan T. Thirunalasundari. 2011. Antioxidant potentials of punica granatum rind extract. International Journal of Pharmacy and Pharmaceutical Science. $3: 82-88$.

Safaryani, N., H. Sri dan D.H. Edah. 2007. Pengaruh suhu dan lama penyimpanan terhadap penurunan kadar vitamin $\mathrm{C}$ brokoli (Brasicca oleracea L). Buletin Anatomi dan Fisiologi. Vol 15 (2).

Sriningsih. 2008. Analisa Senyawa Golongan Flavonoid Herbal Tempuyung (SonchusarvensisL).http://www.indomedia. com/intisari/1999/juni/tempuyung.html. Diakses tanggal: 30 Januari 2015.

Steel, R.G.D dan J.H. Torrie. 1993. Prinsip dan prosedur statistika Suatu Pendekatan Biometrik. Penerjemah B. Sumantri. PT. Gramedia Pustaka, Jakarta.

Tiwari, P., Kumar dan Kaur. 2011. Phytochemical screening and extraction. International Pharmaceutica Scienca. 1 (1) : 98-106.

Utami. 2009. Potensi daun alpukat (Persea americana Mill) sebagai sumber antioksidan alami. Jurnal Teknik Kimia UPN. Jawa Timur. Vol 2 (1) : 58-64.

Vuong, Q.V., S. Hirun dan C.J. Scarlett. 2014. Physicochemical composition, antioxidant and anti-proliferative capacity of a lilly pilly (Syzygium paniculatum) extract. Herbal Medicine. 4:134-140.

Widarta, I. W. R., K. A. Nocianitri dan L. P. I. P. Sari. 2013. Ekstraksi komponen bioaktif ekstrak bekatul beras lokal dengan beberapa jenis pelarut. Jurnal Aplikasi Teknologi Pangan. Vol 2(2): 4-18.

$\mathrm{Xu}, \mathrm{Z}$ dan L.R. Chang. 2012. Analysis of Antioxidant-Rich Phytochemicals. John Wiley and Sons Ltd., UK. p. 208. 